\title{
Cooperative Learning Through Mounier's Personalism in the European Higher Education Area (EHEA)
}

Aprendizaje cooperativo a través del personalismo de Mounier en el Espacio Europeo de Educación Superior (EEES)

Icíar Carmen Jiménez-Barandalla Universidad Rey Juan Carlos (España)

Recibido: 2015-09-29

Enviado a pares: 2015-09-30

Aprobado por pares: 2015-11-12

Aprobado: 2015-11-22

Pensamiento y Cultura | ISSN: 0123-0999 | eISSN: 2027-5331

pensam.cult | Vol. 18-2 | Diciembre de 2015 | pp. 136-161

DOI: 10.5294/pecu.2015.18.2.7

Para citar este artículo/To reference this article

Jiménez-Barandalla, Icíar Carmen. 2015. “Cooperative Learning Through Mounier's Personalism in the European Higher Education Area (EHEA)", Pensamiento y Cultura 18 (2): 136-161. DOI: 10.5294/pecu.2015.18.2.7. 


\title{
Cooperative Learning Through Mounier's Personalism in the European Higher Education Area (EHEA)
}

\begin{abstract}
This paper discusses the need to answer the question of what it is to be a person, if we want to give students a truly all-round education, in accordance with the purposes of the European Higher Education Area. Since the Personalist philosophy of Mounier is built around the concept of the person, we explain the structures of the human person according to Mounier, proposing how they might be promoted in higher education through cooperative learning.
\end{abstract}

Keywords: Education; cooperative learning; Bologna; Mounier; personalist philosophy.

\section{Aprendizaje cooperativo a través del personalismo de Mounier en el Espacio Europeo de Educación Superior (EEES)}

Resumen: en este artículo se discute la necesidad de dar respuesta a la pregunta de qué significa ser una persona, si queremos darles a los estudiantes una educación realmente integral, de conformidad con los objetivos del Espacio Europeo de Educación Superior. Debido a que la filosofía personalista de Mounier se construye alrededor del concepto de la persona, explicamos las estructuras de la persona humana según Mounier y proponemos una manera de promoverlas en la educación superior a través del aprendizaje cooperativo.

Palabras clave: educación; aprendizaje cooperativo; Bolonia; Mounier; filosofía personalista. 
The divergences observed between the competencies of European university graduates and the qualifications required in the business world (Bardhan, Hicks, \& Jaffee 2012; García-Aracil \& Van der Velden 2008; Reyes \& Gálvez 2011; Salas 2012) justify the need to further investigate the educational methods that would best bring to the fore the capacities most needed by students if they are to adapt with greater flexibility to the demands of the labor market. Preparation for the job market, preparation for life - as active citizens in a democratic society (Humphreys 2011)-, personal development, and the acquisition and maintenance of an advanced basis of knowledge are the four purposes defined by the Bologna Working Group on Qualifications Frameworks $(2005,23)$ as goals of the European Higher Education Area (EHEA).

The scope of these targets leads to a comprehensive development of the student implying knowing and understanding, knowing how to act, and knowing how to be (Bologna Working Group 2005); as Bologna proposes the all-round education of the student, the teacher must understand in depth what it means to be a person in order to improve his teaching and only then will advances be made possible in student learning (Stronge, Ward \& Grant 2011).

What is it to be a person? The contribution of this paper is to answer this question on the basis of Mounier's philosophy, and to propose cooperative learning as a methodology for the development of those aspects of the students derive from the proposed concept of the human person.

Personalist philosophy is used in this paper to explore this concept in greater depth for two reasons. The first consists in the fact that this current of philosophical thought is constructed technically around the concept of the person (Burgos 1997), considered the element of experience from which reality is known, and is, moreover, a philosophy committed to solving the problems of everyday life, forming itself again according to what reality requires (Berenguer 2002), which is particularly interesting in a changeable environment like the present. The second reason is based on the concepts of flexibility and constructive criticism that characterize Personalism, which accepts any line of thought which might help to understand reality even when that thought seems contrary to its own theoretical approach (Mounier 1948); this flexibi- 
lity greatly enhances the student's chances of achievement, because it implies a breadth of vision that allows reality to be perceived, not only in one direction, but in all possible directions. Accordingly, given that the changes proposed by the Bologna Plan are based on the need to connect the world of education with real life (Lave and Wenger 1991; Salas, Sanchez-Martínez and Rodríguez-Ferrero 2012), the main reason for using Mounier's line of thought to improve educational methods is its basis in practicality, constructive criticism and commitment, as well as Mounier's desire to move thinking forward.

A substantial body of research (Carpeño et al. 2011; Pérez-Martínez et al. 2010; Reyes and Galvez 2011; Ruiz-Gallardo et al. 2011) evidences the range of competencies defined by the EHEA that students can learn through the different techniques of cooperative work; here we want to emphasize that this methodology is also an appropriate means of implementing Mounerian Personalist philosophy within the educational framework proposed by Bologna. Mounier (1949) sees the person as a relational being, stressing the need for the other that the human being has for his personal growth. Therefore, the student realizes himself, not only in himself, but through others (Martin \& Dowson 2009) and the cooperation promoted by cooperative learning, with its common objectives, mutual rewards, shared resources and complementary roles (Qin, Johnson \& Johnson 1995; Zakaria \& Iksan 2007), fosters precisely those aspects that involve personal growth (Johnson \& Johnson 2005); this allows cooperative learning to be considered a suitable means of achieving the development of the student as a whole person (León et al. 2011). In addition, these personal and relational aspects are realized through the cognitive, volitional and affective faculties of the student which should be comprehensively promoted according to EHEA guidelines.

The purposes of this paper are three. First, it seeks to clarify the concept of the human person by first providing a conceptualization comprising the anthropological existentialist view, and a second conceptualization which adds Mounier's Personalist contributions to the former. Second, using the theoretical research method, it aims to analyze in depth those dimensions of the human person proposed by Mounier, which would enrich the student's all-round development. Third and last, 
and in parallel with the second objective, it synthesizes the suitability of cooperative learning as a methodology for the development of the competencies proposed by Bologna and promoted by the Personalism of Mounier, using the deductive conceptual method.

The starting point is the conceptualization of the human person which will serve as a guide throughout the article and we discuss the extent to which the changes in the concept of education instigated by the Bologna Process can be effected through cooperative learning. In the second and third sections we delve into the personal universe of Mounerian philosophy, explaining how each of the aspects and potentialities of the person can be fostered through cooperation. Finally, we incorporate the contributions of Mounier into the initial concept of the human person, and we suggest further research in order to demonstrate with greater clarity which dimensions of the student must be nurtured and cultivated in the sphere of university education.

\section{Conceptualization of the Human Person and the Suitability of Cooperative Learning to Develop the Competencies of Bologna}

If we want to achieve the all-round development of the student during the educational process, it is essential to take the concept of the human person as our reference point, as only in that way we may know the student in all his breadth and complexity.

This work adopts the anthropological view of the human being of Thomas Aquinas, followed by that of existentialist philosophy and Personalism, which sees the human person as a unity of body and spirit, through which it knows (senses and intelligence), desires (will) and feels (affectivity); both intelligence and will are faculties that refer to another entity, because the person knows something and desires something, whereas affectivity is a purely subjective aspect of the person, which accompanies his actions.

The values of the human person can be explained on this basis, since these are the ideals that guide the person in his personal growth, and in this way generate the motivations or reasons for his actions. Depen- 
ding on his chosen reason, the person will adopt one attitude or another, which will then give shape to the act; these acts may be cognitive and volitional, but the person first knows something -knows the truth of something- and then wants it -if he thinks it is good-, because he cannot desire what he does not known, so that the volitive act must be preceded by the cognitive act. In addition, the attitude adopted towards the act will affect the person's feelings or affective sphere, which always accompanies him in the execution of his acts. Responsibilities arising from such acts will leave scope for a feedback process which, through the emotions, will allow him to judge whether his actions are, indeed, directed towards the fulfillment of his values and, therefore, towards his personal fulfillment.

The main innovation of the Bologna Process is to broaden the concept of education, from a process in which both instruction and acquisition of knowledge predominate, to one in which, besides knowing, the student has to learn to act and to be. Although it is not the object of this research to investigate the different cooperative learning techniques, it is necessary to highlight the suitability of the cooperative learning methodology to the acquisition of the skills considered most important for the professional and personal development of students under the requirements of Bologna, also considering that team work is recognized today as one of the most important demands of the labor market (Mathieu et al. 2008).

Cooperative learning refers to those methods which involve students to work together in small groups or teams to help each other in learning academic discipline (Slavin 1991), or in other words, the educational use of small groups where students work together to maximize their own learning and that of others (Johnson, Johnson \& Holubec 1999a). It is based on promoting positive interdependence, face-to-face interaction, the sense of responsibility of each member of the group, the acquisition of interpersonal and group skills, and group evaluation of the goals they are achieving and the effecting working relationships they are maintaining (Johnson \& Johnson 2009; Slavin 1990, 1996).

Numerous studies reveal that students who have benefitted from cooperative learning haver academic achievements than those who have learned with the traditional methodology (Bowen 2000; Gillies 
2003; Herrmann 2013; Hsiung 2010; Johnson \& Johnson 2002); the works of Bowen (2000), Dochy et al. (2003), Johnson (2003), Johnson and Johnson $(1989,1999,2002,2007)$, Johnson, Johnson and Stanne (2000) and Slavin $(1990,1991,1996,2011)$ should be noted here, as they clarify the results obtained in a large number of studies on cooperative learning. Furthermore, it has been shown that this methodology facilitates the social, emotional and psychological development of students, with regard to social support, quality relationships of students, attitude to learning and learning skills (Gillies 2003, 2008; Johnson \& Johnson 1990; Pinho-Lopes, Macedo, \& Bonito 2011; Smith et al. 2005; Tran \& Lewis 2012); specifically, Bertucci et al. (2010), as well as Chen and Wang (2013) note that students' self-esteem improves in cooperative work because they are involved in cooperative efforts. Also, Johnson and Johnson, R. T. (2009) and Slavin (2011) argue that the positive relationships promoted among students by cooperative learning increase motivation, persistence and degree of commitment to the achievement of group goals, as well as productivity, satisfaction and the sense of personal responsibility for their achievements.

Finally, and in accordance with the EHEA objective of the student's all-round development, this teaching method encourages personal growth since "cooperativeness is positively related to emotional maturity, welladjusted social relations, strong personal identity, ability to cope with adversity, social competencies, basic trust and optimism about people, selfconfidence, independence and autonomy, higher self-esteem, and increased perspective taking skills" (Johnson \& Johnson 2009, 372).

This educational methodology allows an enhancement of all three anthropological aspects of the person, cognitive, volitional and emotional, i.e., it encompasses the totality of the spirit of the human person described above and, thus, embraces the main idea of the Bologna process, which consists in placing students at the core of the learning process. In other words, the term learning refers to an active process on the part of the learner (Barco \& Pérez 2007; Herrmann 2013; Peterson 1997; Von Glasersfeld 1989) by which he acquires not only knowledge, but also the necessary competences for the successful application of this knowledge in his personal and professional life (Smith et al. 2005). 


\section{Mounier's Personalism in the European Higher Education Area}

While Personalism is not wholly identified with Emmanuel Mounier's thought, he is considered the founder and one of the most influential philosophers of this philosophical tendency (Burgos 2005). The choice of this author in reviewing the foundations of education proposed by the EHEA is based on his intention to "awaken every person to his vocation and encourage him toward a life that assures him not the maximum output, but the maximum expansion" (Mounier 1934, 11). One of the challenges of higher education must be precisely to direct students to where they believe they can give most of themselves, that is, to their optimum expansion.

Mounier's philosophy revolves around designated structures of the personal universe, which constitute the basis for understanding the human being and, hence, to determine that the following aspects of the person should be dealt with or developed: unity of body and spirit, communication, inner being, confrontation, conditional freedom, dignity, and commitment.

\section{Unity of Body and Spirit}

According to the Personalist anthropological view, if the human being is understood as a unity of body and spirit, then it is necessary to cultivate both, whilst seeking a balance between them. Mounier clearly expresses this unity of flesh and spirit in person, when he says, "I cannot think without being, or be without my body" $(1949,14)$, and he structures the process of personalization of the human being around this basic anthropological idea.

In higher education it is necessary to highlight the importance of being perceptive vis-à-vis reality, since the more fully the student grasps reality, the greater will be his ability to adapt to it; López (2004) says that person is more independent and free when he is open to and makes the most of the opportunities he has to create something valuable, thus, to offer new opportunities to others in order to enhance their chances.

Thereafter, it is essential that students learn to reason correctly about the reality they are studying, according to their level of knowledge 
on the subject and their level of mental maturity (Vygotsky 1987); this capacity will allow them, first, to properly understand reality in keeping with their experience and previous knowledge, and second, to develop the skills of being creative and decisive in the face of change, to argue a point adequately, to synthesize and structure a speech, and also to develop analytical and research skills.

In this way, students acquire the competencies of knowledge and skills in accordance with the EHEA approach, which considers it essential to involve the student in the reality he is studying so that he can confront difficulties with confidence, and so that he can approach any issue or situation he is presented in a creative way (Birenbaum et al. 2006). Consequently, in this changing environment it is especially interesting to develop the student's creativity because it makes differentiation possible, since it is the stamp of the person, which gives him its unique character (Marín 1998).

\section{Communication}

One of the fundamental principles of Personalism is that the human being should not only look inward, but also outward, because he achieves personal fulfillment not just by and in himself, but also and primarily through others (Rumayor 2010); hence the appropriateness of cooperative learning to the implementation of this philosophy in the development of this ability, which is considered by the EHEA as one of the major skills to be developed in the university taking into account the fact that team work is recognized today as one of the most important demands of the labor market (Mathieu et al. 2008).

Mounier says (1949) that communication presupposes as original acts going outside of oneself, understanding, assuming responsibilities, giving, and being loyal. Capitán (1978) summarizes this attitude as the ability to put aside one's own point of view in order to see something from the viewpoint of others, respecting their uniqueness. The relationship with others requires, if it is to be successful, respect for their being; on this premise, going out of oneself involves discovering all potentialities which, belonging to one's own being and to that of others, can only be realized through communication between them. 


\section{Inner Being}

Mounier considers the person as a union of communication and interiority (1949), bearing in mind the necessary complementarity between both. If the human being cultivates his inner dimension, this can result in improved relations with others, since knowing himself involves discovering the potentialities of the person, many of which cannot become real without the participation of other people. Both aspects are essential for personal growth, but it is essential to find a balance between the subjectivity which comes from privacy and the objectivity invited by communication, such one may nourish the other.

The human being needs to look within himself to deepen his thoughts and to find the basis of every decision in the direction of his life; in this way his inner life is enriched and new possibilities of action open up which may also benefit others. The interiority of the person is directly related to the sense of purpose or vocation which he seeks to realize through his actions and that may be simply a value, such as justice, truth, or love, or that may be defined by his calling or profession.

According to the guidelines of EHEA, the educator must serve as a guide or a model (De Miguel 2006). From the point of view of Mounerian Personalism this mission of the teacher is crucial, as it helps the student to discover his goal and to value his freedom, from which he can decide what to do in order to grow as a person.

\section{Confrontation}

There is an essential link between the decisions that a person makes in the course of his life, because through them he is making his way to his goal, or in Mounier's words, "when I choose this or that, I choose myself indirectly in each decision, and in making the choice, I am constructing myself" $(1949,37)$.

In education, therefore, it is essential that the teacher respects the freedom of the student and lets him make his own decisions, even at the risk of being wrong, so that he can learn from his failures and strengthen his self-esteem (González 2003; Mounier 1957). Teacher's role is to accompany the student in order to help him discover his achievements, and to encourage him in the face of difficulties, so that he gains confidence 
and his self-esteem is boosted. Mounier suggests "we must restore the person's sense of responsibility and of his enormous power when he has faith in himself" $(1949,47)$.

\section{Conditional Freedom}

The sense of freedom with which person is born enables him in the course of his life to achieve his independence, and that is where education plays a fundamental role. To understand the possibilities available for self-fulfillment in a person it is essential to understand that, like all his being, his freedom is limited, restricted, conditional, since he will otherwise think he has rights that are not in fact his due. A person's own way of being, his freedom, is conditioned by what is given to him, as such Mounier (1949) highlights:

I am given to myself and the world preexists me. This being my nature, there are multiple factors weighing on my very freedom, that which comes from myself, from my particular being which limits it, and that which comes from the world, from the necessities which constrain it and the values which drive it. (34)

Rules are the limits that force a person to be respectful, to be aware of his/her circumstances, and to consider the benefits or damages that his hypothetical action would entail for people or things. Only this responsible kind of freedom ensures survival and coexistence and it must, therefore, be exercised with extreme vigilance.

It is vital to make the learner understand this concept of conditional freedom from his earliest years, by gradually helping him to take personal responsibility for his decisions. It is necessary to stress that everyone must bear the consequences of his actions, so that, knowing himself responsible for them, the person learns to properly consider the positive and negative aspects of each decision, and to act prudently.

\section{Dignity}

Communication enriches only if the person is able to recognize the dignity of the other. What determines the dignity of a being is what 
that being is, and, consequently, it is the transcendence and the spiritual nature of the human being which make him worthy of his lofty dignity (Mounier 1962) and of the high degree of respect due to him.

The role of education in this regard should be to make the person expect much of himself in his respect for and compliance with the previously mentioned values of truth and goodness, because this is the way in which he can uphold his dignity and grow as person.

Every human being is forced into a relationship with the other, and that relationship often requires, at least partially, the sacrifice of own interests; the person must, therefore, accept this condition for his personal growth. The principle of treating a person as an end in himself and never as a means to an end, must become the watchword of his actions and feelings, if he wants to show respect for his dignity and that of others.

\section{Commitment}

Commitment and action are closely linked in Mounerian philosophy, and action is key in Personalism also because, as a practical philosophy, it does not admit mere reflection on ideas which are not then translated into reality.

All structures of the universe of the Mounerian person converge in this final one, along with several of the central ideas of his philosophy and their important connection with the main function of education in the formation of the person. Students must be taught that spirit is not given to them totally realized, but that it has the capacity to surpass what is given with what they build upon it (Lacroix 1950); in other words, it is important to grow the student confidence in his own potential.

Freedom transforms the person into a being with infinite opportunities to surpass himself through action. In each action the person performs, he goes forward or backward in the realization of his being and consequently, he is impoverished or enriched as a person. However, for this action to be effective, the person must, as well as being persistent and taking responsibility for his actions, commit himself to channeling all his actions in the same direction, towards what he has chosen as his life goal. 
The educator's role from the point of view of Mounier's philosophy can, therefore, be summed up as helping students to become aware of their potential and teaching them to realize it.

\section{Implications for Practice of Mounier's Thought Through Cooperative Learning}

This section aims to analyze in depth how those dimensions of the human person proposed by Mounier would be developed in practice through cooperative learning.

\section{Unity of Body and Spirit}

Since truth lies in judgment, and is an adaptation between reality and intelligence, the teacher's role is to enlighten the truth of a reality which at first seems distant, complicated or hidden, in a process that always goes from the exterior and concrete level of the reality, to the deep and abstract level of knowledge. All people have a natural desire to know (Aristotle trans. 2005) and extending this desire must be a joint task, of research, of going deeper, of the progressive discovery of reality and of becoming open to creativity, in which the teacher must involve the student.

The construction of knowledge is especially rich in cooperative learning, because it takes place in two parallel processes; on the one hand, the reality to be studied is perceived and apprehended by each group member individually, but on the other hand, when what each member of the team has perceived about that experience is shared, a collective knowledge of it is constructed, which will be more complete and deeper than individual knowledge (Huber 2008).

\section{Communication}

For communication to be effective, the people who participate in it must adopt an empathetic attitude requiring, besides respect, other attitudes such as dialogue, active listening, flexibility and constructive criticism. These attitudes can be cultivated through cooperative learning (Johnson 2003); they will generate confidence in other people and will strengthen personal relationships (Johnson \& Johnson 2009). 
Moreover, since the values of truth and goodness are what really motivate human beings (Arp 2007), communication between students will be better if it is based on values which can also be promoted using this methodology, such as equality (Johnson \& Johnson 1996), commitment (Johnson \& Johnson 2005; Slavin 2011), doing good (Melé 2009; Tran \& Lewis 2012) and working on behalf of the community (Johnson \& Johnson 2005; Slavin 2011). Regarding equality, the dependence of each human being on others for his balanced growth is based on the fact that, whilst all people have the same essential characteristics, they possess different ways of being, and this dependence leads to communication and the creation of communities (Aristotle, trans. 1981).

If the teacher guides communication by these principles, he will obtain better results in the development of the personal, interpersonal and organizational skills and attitudes that are traditionally associated with cooperative learning (Melroth \& Deering 1994).

When his senses of community and of equality are enhanced, the student feels respected and integrated into the classroom and the group, and this positive feeling (Jiménez 2012; Martin \& Dowson 2009) will motivate him to adopt a more open and confident attitude towards accepting the contributions and constructive criticism of peers (Johnson et al. 1999b).

Regarding interpersonal skills, perceptions of community and equality will allow the student to feel more free and confident in his ability to play different roles within the group (Johnson 2003), and more motivated to develop certain attitudes, such as expressing disagreement or incomprehension (Lobato 1997), giving support and recognizing the contribution of others (Gillies 2003; Johnson \& Johnson 2008; Johnson et al. 1999b; Tran \& Lewis 2012).

Finally, with regard to organizational skills, when all students feel equal, there will be a greater commitment to another value, namely that of seeking the common good, and, therefore, students will be encouraged to adopt attitudes such as considering other opinions and respecting rules, and skills such as focusing on group goals and reaching group consensus (Chen \& Wang 2013; Johnson \& Johnson 2009; Johnson et al. 1999b; Slavin 2011). 


\section{Inner Being}

The student needs to see in the teacher a person with consistent criteria in his actions (Cassin \& Büttgen 2010), who is persistent in the pursuit of his goals, and who takes responsibility for his actions. In other words, in the course of his university career, the student should gradually see what his goals are, and the best way the teacher can guide him in this decision is with regard to how pursue them, since, whatever they may be, they can be attained through self-regulation, commitment, perseverance and responsibility.

Cooperative learning facilitates the development of the value which motivates a person to adopt this attitude, since this value is his own personal good, and teamwork shows that acting on the basis of these criteria leads to better long-term results, as previously explained. So, if the teacher teaches the student to use his willpower to maintain this attitude in his relationship with the members of his team, the student will see the benefit obtained for the group by so doing, and will continue to adopt it in the pursuit of his own personal goals.

\section{Confrontation}

The fear of failure limits a person's freedom of action and, consequently, his creativity in achieving personal fulfillment, because of which it is important for the teachers to stress the importance of being able to meet challenges, rather than focusing on their outcome. Group work allows individual responsibility to be diluted in that of the group, thus encouraging its members when they have to carry out their tasks; however, the fact that each person knows that he is responsible not only for his own success and failure, but also for that of the other team members, exerts a pressure that will prevent him from relaxing his efforts. In addition, as mentioned above, cooperative learning allows the playing of different roles on a rotating basis within the group (Johnson et al. 1999b), e.g., leader, organizer, facilitator, coordinator, observer or secretary; this helps the student to identify his strengths and weaknesses in each role that he plays within the group, and to assess the degree to which he needs to improve his ability to address these different roles in his life. 


\section{Conditional Freedom}

Cooperative learning provides an exceptionally good context in which the student can become aware of his conditional and responsible freedom, because, on the one hand, he will have to comply with certain rules, which must be explained to him by the teacher, in order to participate in teamwork (Veenman et al. 2005), and, on the other hand, his actions will affect the other members of the group and he must, therefore, answer to them for the consequences of his decisions (Johnson \& Johnson 1999). Consequently, these are excellent opportunities in which students can learn to set limits on the actions of those who do not respect the freedom of others, and in which each of them can become aware of his own limitations and of his responsibility towards every decision taken. In addition to helping the student to become more mature, this will have a beneficial influence on his own creativity (Johnson \& Johnson 1999), because it is thanks to this encounter with others that the person can create.

\section{Dignity}

Teamwork clearly illustrates that the student is forced to give up part of his individual interests in favor of those of the group, but in return for results, achieved by all, which produce personal progress and growth (Slavin 2011; Tran \& Lewis 2012). To achieve this it is important for the teacher to communicate an attitude of respect and of giving support unselfishly, as well as to develop certain skills, such as obtaining synergies from the contributions of team members, resolving conflicts positively, reducing tensions in the group and seeking consensus (Johnson et al. 1999b); in addition, he must highlight the emotions resulting from this attitude, i.e., admiration for the person who has provided support (Lobato 1997) and satisfaction from helping those on the team who need support (Chen \& Wang 2013; Sharan 1980; Slavin 2011).

\section{Commitment}

Attitudes of responsibility, perseverance and commitment, in addition to the aforementioned flexibility, constructive criticism, dialogue and support, can be promoted through cooperative learning and they are important, not only for the good of the group, but also for the good 
of each member of the team according to his personal goals. Martin and Dowson (2009) emphasize that connectivity on a personal and emotional level in the academic context provides scope for the students' commitments and achievements.

The development of these attitudes through cooperative learning will strengthen student's self-esteem (Bertucci et al. 2010; Johnson and Johnson 1999; Johnson et al. 1999b; Slavin 1991, 2011; Tran and Lewis 2012), and this will enable them to manage stress and adversity, and to remain committed to attaining the primary goal they have chosen for their life (Johnson and\& Johnson, 1999). The educator must respect the option chosen by the student, but his function, as guide, can be very valuable to show him how to give the most of himself.

\section{Suggestions for Further Research}

In this fourth and last section we suggest to complement the initial concept of the person with the contributions of other educators, as John H. Newman (Morales 2003; Newman 1996) and Ernest L. Boyer (Boyer 1997; Jacobsen \& Jacobsen 2013), in order to clarify all those aspects of the student, which must be discussed if the goal is his all-round education and personal growth.

With reference to the contribution of Mounier, he stresses the Thomist anthropological view of considering the human being as a unity of body and spirit in the necessary balance to permit his full and healthy self-realization, and the development of his creativity. He further emphasizes the personal growth of the human being, which is nourished from two sources: One, his own self, which involves the nurturing of his inner being and steers the free choice of goal that gives meaning to his life; the other, an entity distinct from himself, produced through communication, enriched through cooperation between people, and thus leading to the existence of the community.

Everything that encompasses the human person defines his dignity, specifically his capacity for transcendence and his spiritual nature. His dignity determines the values which motivate his actions, and since, as explained above, the person is oriented by his essence to seek what is true 
and to desire what is good (Aristotle, trans. 2004), these are his core values. However, it is difficult to act in accordance with these values when the person is forced to confront reality and is free to choose; so with regard to the former, the student must commit himself to being persistent in his self-regulation, and with regard to the latter, he must learn to respect the limits imposed by the existence of others, to take responsibility for his actions, and to use his creativity to fulfill himself. If he succeeds in acting in accordance with his values, he will improve his self-esteem and this, in turn, will strengthen his sense of his dignity as a person (Delgado 2010).

This paper proposes cooperative learning as an appropriate methodology to help student to discover and understand these different structures that shape him. However, it would be interesting to investigate other ways in which the teacher must make the student see what he is capable of and help him develop more fully those aspects of himself which, ultimately, can help the student to overcome the challenges of his personal and professional lives.

\section{References}

Aristotle. 1981. La política [Politics] (2nd ed.). Madrid: Editora Nacional. Aristotle. 2004. Etica a Nicómaco [Nicomachean Ethics]. Madrid: Alianza Editorial.

Aristotle. 2005. Metafísica [Metaphysics]. Madrid: Espasa Calpe.

Arp, Robert. 2007. "Vindicating Kant's morality". International Philosophical Quarterly, 47(1): 5-22. doi:10.5840/ipq200747155

Barco, Benito León del, and Latas, Carlos. 2007. "The formation in techniques of cooperative learning of the university professor in the context of the European convergence". Revista de Psicodidáctica, 12(2): 269-277. http://dx.doi.org/10.1387/RevPsicodidact.224

Bardhan, Ashok; Hicks, Daniel, and Jaffee, Dwight. 2012. "How responsive is higher education? The linkages between higher education and the labor market". Applied Economics, 45(10): 1239-1256. doi:1 0.1080/00036846.2011.613801 
Berenguer, Enrique. 2002. Hacia una pedagogía del Personalismo comunitario [Towards a pedagogy of community Personalism]. Madrid: Fundación Emmanuel Mounier.

Bertucci, Andrea; Conte, Stella; Johnson, David W, and Johnson, Roger T. 2010. "The impact of size of cooperative group on achievement, social support, and self-esteem". The Journal of General Psychology, 137(3): 256-272. doi:10.1080/0022, 1309.2010.484448

Birenbaum, Menucha; Breuer, Klaus; Cascallar, Eduardo; Dochy, Filip; Dori, Judy; Ridgway, Jim; Wiesemes, Rolf, and Nickmans, Goele. 2006. "A learning integrated assessment system". Educational Research Review, 1(1): 61-67. doi:10.1016/j.edurev.2006.01.001

Bologna Working Group on Qualifications Frameworks. 2005. A framework for qualifications of the European Higher Education Area. Copenhagen (DK): Ministry of Science, Technology and Innovation. Retrieved from http://www.bologna-bergen2005.no/Docs/00Main_doc/050218_QF_EHEA.pdf

Bowen, Craig. 2000. "A quantitative literature review of cooperative learning effects on high school and college chemistry achievement". Journal of Chemical Education, 77(1): 116. doi:10.1021/ed077p116

Boyer, Ernest L. 1997. Scholarship reconsidered: Priorities of the professoriate. San Francisco: Jossey-Bass.

Burgos, Juan Manuel. 1997. “Es posible definir el personalismo?” [Is it possible to define Personalism?] In A. Quirós, A. Sarmiento, E. Molina, J. Enériz, \& J. Peñacoba (Eds.), El primado de la persona en la moral contemporánea (pp. 143-152). Pamplona: Eunsa. Retrieved from http://hdl.handle.net/10171/5564

Burgos, Juan Manuel. 2005. "Algunos rasgos esenciales de la antropología personalista" [Some essential features of Personalist anthropology]. Thémata, 35: 495-500. Retrieved from http://www.publius. us.es/themata/indice_contenidos/num_35

Capitán, Alfonso. 1978. "Persona y educación en Mounier" [Person and education in Mounier]. Revista Española de Pedagogía, 139: 55-66.

Carpeño, Antonio; Arriaga, Jesús; Corredor, Javier, and Hernández, Javier 2011. "The key factors of an active learning method in a 
microprocessors course". IEEE Transactions on Education, 54(2): 229-235. doi:10.1109/TE.2010.2048753

Cassin, Barbara, and Büttgen, Philippe 2010. “The performative without condition. A university sans appel”. Radical Philosophy, 162. http:// www.radicalphilosophy.com/article/\%EF\%BB\%BFthe-performative-without-condition

Chen, Jing, and Wang, Ying. 2013. "A study of cooperative learning in higher college English teaching". Theory and Practice in Language Studies, 3(7): 1258-1263. doi:10.4304/tpls.3.7.1258-1263

De Miguel, Mario Coord. 2006. Metodologías de enseñanza y aprendizaje para el desarrollo de competencias. Orientaciones para el profesorado universitario ante el Espacio Europeo de Educación Superior [Methodologies of teaching and learning for skills development. Guidelines for faculty in the European Higher Education Area]. Madrid: Alianza Editorial.

Delgado, Ignacio. 2010. “Perspectiva antropológica de la educación. Visión desde la filosofía dialógica y personalista" [Anthropological basis for education]. Revista Española de Pedagogía, 68(247): 479-495. Retrieved from http://dialnet.unirioja.es/servlet/articulo? codigo=3300562

Dochy, Filip; Segers, Mien; Van den Bossche, Piet, and Gijbels, David. 2003. "Effects of problem-based learning: A meta-analysis". Learning and Instruction, 13: 533-568. doi:10.1016/S0959-4752(02)00025-7

Forment, Eudaldo 1996. "La sistematización de Santo Tomás de los trascendentales" [The systematization of the transcendentals of Thomas Aquinas]. Contrastes. Revista Interdisciplinar de Filosofía, 1: 107-124. Retrieved from http://dialnet.unirioja.es/servlet/articulo? codigo $=190407$

García-Aracil, Adela, and Van der Velden, Rolf 2008. "Competencies for young European higher education graduates: Labor market mismatches and their payoffs". Higher Education, 55: 219-239. doi:10.1007/ s10734-006-9050-4

Gillies, Robin. 2003. "Structuring cooperative group work in classrooms". International Journal of Educational Research, 39(1,2): 35-49. doi:10.1016/S0883-0355(03)00072-7 
González, Ana Marta. 2003. "Ethics is global business and in a plural society". Journal of Business Ethics, 44(1): 23-36. Retrieved from http://hdl.handle.net/10171/16849

Herrmann, Kim J. 2013. "The impact of cooperative learning on student engagement: Results from an intervention". Active Learning in Higher Education. Published online before print September 12. doi:10.1177/1469787413498035

Hsiung, Chin-Min 2010. "An experimental investigation into the efficiency of cooperative learning with consideration of multiple grouping criteria”. European Journal of Engineering Education, 35(6): 679-692. doi:10.1080/03043797.2010.511149

Huber, Günter. L. 2008. "Aprendizaje activo y metodologías educativas" [Active learning and methods of teaching]. Revista de Educación, No. Extra: 59-81. http://hdl.handle.net/11162/72275

Humphreys, Melanie. J. 2011. "A new generation of leaders for Eastern Europe: Values and attitudes for active citizenship". Christian Higher Education, 10(3-4): 215-236. doi:10.1080/15363759.2011.576209

Jacobsen, Douglas, and Jacobsen, Rhonda H. 2013. “The religious roots of Ernest L. Boyer's educational vision: A theology of public pietism”. Christian Higher Education, 13(1): 17-28, doi:10.1080/15363759.2014.856648

Jiménez, Rocío. 2012. "Educación inclusiva y formación inicial del profesorado: Evaluación de una innovación didáctica basada en la producción cinematográfica desde la perspectiva del alumnado". [Inclusive education and initial teacher training: Evaluation of a didactic innovation based on filmmaking from a student's perspective]. Revista de Educación, 359: 232-259. http://hdl.handle. net/11162/95240

Johnson, David W. 2003. "Social interdependence: The interrelationships among theory, research, and practice". American Psychologist, 58(11): 934-945. doi:10.1037/0003-066X.58.11.934

Johnson, David W, and Johnson, Frank 2009. Joining together: Group theory and group skills. (10th ed.). Boston: Allyn \& Bacon.

Johnson, David W, and Johnson, Roger T. 1989. Cooperation and competition: Theory and research. Edina, MN: Interaction Book Company. 
Johnson, David W, and Johnson, Roger T. 1990. "Social skills for successful group work”. Educational Leadership, 47(4): 29-33. Retrieved from http://www.ascd.org/publications/educational-leadership/dec89/vol47/num04/toc.aspx

Johnson, David W, and Johnson, Roger T. 1996. "Cooperative learning and traditional American values: An appreciation". NASSP Bulletin, 80(579): 63-65. doi:10.1177/019263659608057911

Johnson, David W, and Johnson, Roger T. 1999. "What makes cooperative learning work”. In David Kluge, Saundra McGuire, David W. Johnson, \& Roger T. Johnson (Eds.), Cooperative learning (pp. 23-36). Tokio: Japan Association for Language Teaching.

Johnson, David W, and Johnson, Roger T. 2002. "Cooperative learning methods: A meta-analysis". Journal of Research in Education, 12(1): 5-14. Retrieved from http://www.eeraonline.org/journal/2002.cfm

Johnson, David W., and Johnson, Roger T. 2005. "New developments in social interdependence theory". Genetic, Social \& General Psychology Monographs, 131(4): 285-358. doi:10.3200/MONO.131.4

Johnson, David W, and Johnson, Roger T. 2007. “The state of cooperative learning in postsecondary and professional settings". Educational Psychology Review, 19(1): 15-29. doi:10.1007/s10648-006-9038-8

Johnson, David W, and Johnson, Roger T. 2008. "Social interdependence theory and cooperative learning: The teacher's role". In Robyn M. Gillies, Adrian Ashman, \& Jan Terwel (Eds.), Teacher's role in implementing cooperative learning in the classroom (pp. 9-37). New York: Springer. doi:10.1007/978-0-387-70892-8_1

Johnson, David W, and Johnson, Roger. T. 2009. "An educational psychology success story: Social interdependence theory and cooperative learning". Educational Researcher, 38(5): 365-79. doi:10.3102/0013189X09339057

Johnson, David W; Johnson, Roger. T, and Holubec, Edythe J. 1999a. El aprendizaje cooperativo en el aula [Cooperation in the classroom]. Buenos Aires: Paidós.

Johnson, David W; Johnson, Roger T, and Holubec, Edythe J. 1999b. Los nuevos círculos del aprendizaje. La cooperación en el aula y la 
escuela [The new circles of learning. Cooperation in the classroom and school]. Buenos Aires: Aiqué.

Johnson, David W; Johnson, Roger T, and Stanne, Mary B. 2000. Cooperative learning methods: A meta-analysis. Minneapolis, $\mathrm{MN}$ : University of Minnesota Press.

Lacroix, Jean. 1950. "Mounier éducateur" [Mounier educator]. Esprit, 174: 839-851. Retrieved from http://www.esprit.presse.fr/archive/ review/article.php? code $=34142 \&$ folder $=0$

Lave, Jean, and Wenger, Etienne 1991. Situated learning: Legitimate peripheral participation. Cambridge: Cambridge University Press.

León, Benito; Felipe, Elena; Iglesias, Damián, and Latas, Carlos. 2011. "El aprendizaje cooperativo en la formación inicial del profesorado de Educación Secundaria" [Cooperative learning in the initial training of Secondary School teachers]. Revista de Educación, 354: 715-729. doi:10.4438/1988-592X-RE-2011-354-017

Lobato, Clemente. 1997. "Hacia una comprensión del aprendizaje cooperativo" [Towards an understanding of cooperative learning]. Revista de Psicodidáctica, 4: 59-76. doi:10.1387/RevPsicodidact.58

López, Alfonso. 2004. La experiencia estética y su poder formativo [Aesthetic experience and its formative power] (2nd ed.). Bilbao: Deusto.

Marín, Ricardo. 1998. La creatividad: Diagnóstico, evaluación e investigación [Creativity: Diagnosis, evaluation and research]. Madrid: UNED.

Martin, Andrew. J, and Dowson, Martin. 2009. “Interpersonal relationships, motivation, engagement, and achievement: Yields for theory, current issues, and educational practice". Review of Educational Research, 79(1): 327-365. doi:10.3102/0034654308325583

Mathieu, John; Maynard, M. Travis; Rapp, Tammy, and Gilson, Lucy 2008. "Team effectiveness 1997-2007: A review of recent advancements and a glimpse into the future". Journal of Management, 34: 410-476. doi:10.1177/0149206308316061

Melé, Domènec. 2009. "Integrating Personalism into virtue-based business ethics: The Personalist and the common good principles". Journal of Business Ethics, 88(1): 227-244. doi:10.1007/s10551-009-0108-y 
Melroth, Michel, and Deering, Paul. 1994. "Task talk and task awareness under different cooperative learning conditions". American Educational Research Journal, 31(1): 138-165. doi: 10.3102/00028312031001138

Morales,José.2003. “Newman’sIdeaofaUniversitymakessensetoday”.Christian Higher Education, 2(3): 197-211. doi:10.1080/20033691918738

Mounier, Emmanuel. 1934. El Movimiento Esprit y la revolución espiritual [The Esprit movement and the spiritual revolution]. Madrid: Cruz y Raya.

Mounier, Emmanuel. 1948. "Tareas actuales de un pensamiento de inspiración personalista" [Current tasks for thinking inspired by Personalism]. In Emmanuel Mounier, Mounier en Esprit. 1997. Madrid: Caparrós.

Mounier, Emmanuel. 1949. Le Personnalisme [Personalism]. Paris: Presses universitaires de France. Reprinted in Mounier (1962).

Mounier, Emmanuel. 1957. El miedo del siglo XX [The little fear of the twentieth century]. Madrid: Taurus.

Mounier, Emmanuel. 1962. Oeuvres III: 1944-1950 [Works III]. Paris: Seuil.

Newman, John. Henry. 1996. The idea of a university. New Haven and London: Yale University Press.

Novak, Joseph D. 1991. "Ayudar a los alumnos a aprender cómo aprender" [Helping students learn how to learn]. Enseñanza de las Ciencias, 9(3): 215-228. Retrieved from http://dialnet.unirioja.es/ servlet $/$ articulo? codigo $=94518$

Pérez-Martínez, Jorge. Enrique; García, Javier; Muñoz, Isabel, and Sierra-Alonso, Almudena. 2010. "Active learning and generic competences in an operating systems course". International Journal of Engineering Education, 26(6): 1484-1492. Retrieved from http:// www.ijee.ie/ contents/c260610.html

Peterson, Michael 1997. "Skills to enhance problem-based learning". Medical Education Online, 2: 3. Retrieved from http://med-ed-online.net/index.php/meo/article/viewFile/4289/4480 
Pinho-Lopes, Margarida; Macedo, Joaquim, and Bonito, Fernando. 2011. "Cooperative learning in a Soil mechanics course at undergraduate level”. European Journal of Engineering Education, 36(2): 119-135. doi:10.1080/03043797.2011.565115

Qin, Zhining; Johnson, David W, and Johnson, Roger T. 1995. “Cooperative versus competitive efforts and problem solving". Review of Educational Research, 65(2): 129-143. doi:10.3102/00346543065002129

Reyes, Encarnación, and Gálvez, Jaime C. 2011. "Introduction of innovations into the traditional teaching of construction and building materials". Journal of Professional Issues in Engineering Education and Practice, 137(1): 28-37. doi:10.1061/(ASCE)EI.1943-5541.0000033

Ruiz-Gallardo, José-Reyes; Castaño, Santiago; Gómez-Alday, Juan J, and Valdés, Arturo. 2011. "Assessing student workload in problem based learning: Relationships among teaching method, student workload and achievement. A case study in natural sciences". Teaching and Teacher Education, 27(3): 619-627. doi:10.1016/j.tate.2010.11.001

Rumayor, Miguel. A. 2010. "Aspectos de formación ética en la educación para la ciudadanía según el personalismo de Xavier Zubiri”. [Aspects of ethics training in education for citizenship according to the personalism of Xavier Zubiri]. Revista de Educación, 353: 693-704. http://hdl.handle.net/11162/79921

Salas, Manuel. 2012. "More than just good grades: Candidates' perceptions about the skills and attributes employers seek in new graduates". Journal of Business Economics and Management, 13(3): 499-517. doi: 10.3846/16111699.2011.620150

Salas, Manuel; Sánchez-Martínez, María Teresa, and Rodríguez-Ferrero, Noelina. 2012. "Developing generic competencies in the European Higher Education Area: A proposal for the teaching of the principles of economics". European Journal of Education, 47(3): 462-476. doi:10.1111/j.1465-3435.2012.01525.x

Sharan, Shlomo. 1980. "Cooperative learning in small groups: Recent methods and effects on achievement, attitudes and ethnic relations". Review of Educational Research, 50(2): 241-271. doi:10.3102/00346543050002241 
Slavin, Robert E. 1990. Cooperative learning: Theory, research, and practice (2nd ed.). New Jersey: Prentice Hall.

Slavin, Robert E. 1991. "Synthesis of research on cooperative learning". Educational Leadership, 48(5): 71-82. Retrieved from http://www.ascd. org/publications/educational-leadership/feb91/vol48/num05/toc.aspx

Slavin, Robert E. 1996. "Research on cooperative learning and achievement: What we know, what we need to know". Contemporary Educational Psychology, 21(1): 43-69. doi:10.1006/ceps.1996.0004

Slavin, Robert E. 2011. "Instruction based on cooperative learning". In R E. Mayer, \& P. A. Alexander (Eds.), Handbook of research on learning and instruction (pp. 344-360). New York: Taylor \& Francis.

Smith, Karl A; Sheppard, Sheri D; Johnson, David W, and Johnson, Roger T. 2005, "Pedagogies of engagement: Classroom-based practices". Journal of Engineering Education, 94: 87-101. doi:10.1002/j.2168-9830.2005.tb00831.x

Stronge, James H; Ward, Thomas J, and Grant, Leslie W. 2011. "What makes good teachers good? A cross-case analysis of the connection between teacher effectiveness and student achievement". Journal of Teacher Education, 62(4): 339-355. doi:10.1177/0022487111404241

Tran, Van Dat, and Lewis Ramon. 2012. "Effects of cooperative learning on students at a Giang university in Vietnam". International Education Studies, 5(1): 86-99. doi:10.5539/ies.v5n1p86

Von Glasersfeld, Ernst. 1989. "Cognition, construction of knowledge, and teaching”. Synthese, 80(1): 121-140. doi:10.1007/BF00869951

Vygotsky, Lev S. 1987. The collected works of L. S. Vygotsky. Vol. I: Problems of general psychology. New York: Plenum Press.

Zakaria, Effandia, and Iksan, Zanaton. 2007. "Promoting cooperative learning in science and mathematics education: A Malaysian perspective". Eurasia Journal of Mathematics, Science \& Technology Education, 3(1): 35-39. http://www.ejmste.com/v3n1/ abstv3n1artc4_zakaria.html 